\title{
Front Matter: Volume 7001
}

, "Front Matter: Volume 7001," Proc. SPIE 7001, Photonics in Multimedia II, 700101 (17 June 2008); doi: 10.1117/12.802444

SPIE. Event: SPIE Photonics Europe, 2008, Strasbourg, France 


\title{
PROCEEDINGS OF SPIE
}

\section{Photonics in Multimedia II}

\author{
Ari Tervonen \\ Frank Möllmer \\ Editors
}

9-10 April 2008

Strasbourg, France

Sponsored by

SPIE Europe

Cosponsored by

Alsace International (France)

Conseil Général du Bas-Rhin (France)

Région Alsace (France)

Communauté Urbaine de Strasbourg (France)

Cooperating Organizations

AFOP_Association Française des Industries de l'Optique et de la Photonique (France)

EOS-European Optical Society (Germany) - EPIC-European Photonics Industry Consortium

(France) • ePIXnet (Belgium) • IOP_Institute of Physics (United Kingdom) • NEMO—Network of

Excellence on Micro-Optics (Belgium) • OLAS (Italy) • The OLLA Project (Germany) • OPERA 2015

(Belgium) • PhOREMOST (Ireland) • Photonics Knowledge Transfer Network (United Kingdom)

Photonics Cluster (United Kingdom) • Photonics4Life (Germany) • Photonics 21 (Germany)

RhenaPhotonics Alsace (France)

Published by

SPIE

Volume 7001

Proceedings of SPIE, 0277-786X, v. 7001 
The papers included in this volume were part of the technical conference cited on the cover and title page. Papers were selected and subject to review by the editors and conference program committee. Some conference presentations may not be available for publication. The papers published in these proceedings reflect the work and thoughts of the authors and are published herein as submitted. The publisher is not responsible for the validity of the information or for any outcomes resulting from reliance thereon.

Please use the following format to cite material from this book:

Author(s), "Title of Paper," in Photonics in Multimedia II, edited by Ari Tervonen, Frank Möllmer, Proceedings of SPIE Vol. 7001 (SPIE, Bellingham, WA, 2008) Article CID Number.

ISSN 0277-786X

ISBN 9780819471994

Published by

SPIE

P.O. Box 10, Bellingham, Washington 98227-0010 USA

Telephone +1 3606763290 (Pacific Time) · Fax +1 3606471445

SPIE.org

Copyright (C 2008, Society of Photo-Optical Instrumentation Engineers

Copying of material in this book for internal or personal use, or for the internal or personal use of specific clients, beyond the fair use provisions granted by the U.S. Copyright Law is authorized by SPIE subject to payment of copying fees. The Transactional Reporting Service base fee for this volume is $\$ 18.00$ per article (or portion thereof), which should be paid directly to the Copyright Clearance Center (CCC), 222 Rosewood Drive, Danvers, MA 01923. Payment may also be made electronically through CCC Online at copyright.com. Other copying for republication, resale, advertising or promotion, or any form of systematic or multiple reproduction of any material in this book is prohibited except with permission in writing from the publisher. The CCC fee code is $0277-786 \mathrm{X} / 08 / \$ 18.00$.

Printed in the United States of America.

Publication of record for individual papers is online in the SPIE Digital Library.

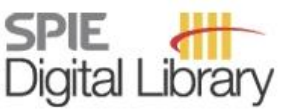

SPIEDigitallibrary.org

Paper Numbering: Proceedings of SPIE follow an e-First publication model, with papers published first online and then in print and on CD-ROM. Papers are published as they are submitted and meet publication criteria. A unique, consistent, permanent citation identifier (CID) number is assigned to each article at the time of the first publication. Utilization of CIDs allows articles to be fully citable as soon they are published online, and connects the same identifier to all online, print, and electronic versions of the publication. SPIE uses a six-digit CID article numbering system in which:

- The first four digits correspond to the SPIE volume number.

- The last two digits indicate publication order within the volume using a Base 36 numbering system employing both numerals and letters. These two-number sets start with 00, 01, 02, 03, 04, 05, $06,07,08,09,0 A, 0 B \ldots 0 Z$, followed by $10-12,20-2 Z$, etc.

The CID number appears on each page of the manuscript. The complete citation is used on the first page, and an abbreviated version on subsequent pages. Numbers in the index correspond to the last two digits of the six-digit CID number. 


\section{Contents}

$\checkmark \quad$ Conference Committee

\section{SESSION 1 3D AND IMMERSIVE DISPLAYS}

700102 Optical characterization and measurements of autostereoscopic 3D displays [7001-01] M. Salmimaa, T. Järvenpää, Nokia Research Ctr. (Finland)

700103 Demonstration of a polarization-based full-color stereoscopic projection display using liquid crystal on silicon panels and light emitting diodes [7001-02]

L. Bogaert, Y. Meuret, B. Van Giel, Vrije Univ. Brussel (Belgium); H. Murat, Univ. Gent (Belgium); H. De Smet, Univ. Gent (Belgium) and Interuniversity MicroElectronics Ctr. (Belgium); H. Thienpont, Vrije Univ. Brussel (Belgium)

700104 Development of monocular and binocular multi-focus 3D display systems using LEDs [7001-03]

S.-K. Kim, D.-W. Kim, Korea Institute of Science and Technology (South Korea); J.-Y. Son, Daegu Univ. (South Korea); Y.-M. Kwon, Korea Institute of Science and Technology (South Korea)

700105 Diffractive exit-pupil expander with a large field of view [7001-04]

P. Saarikko, Nokia Research Ctr. (Finland)

700106 Compact near-to-eye display with integrated gaze tracker [7001-05]

T. Järvenpää, V. Aaltonen, Nokia Research Ctr. (Finland)

700107 Synfograms: a new generation of holographic applications [7001-06]

O. Meulien Öhlmann, D. Öhlmann, Syn4D GmbH (Germany); S. J. Zacharovas, Geola

(Lithuania)

\section{SESSION 2 CAMERA SENSORS AND SIGNAL PROCESSING}

700108 Small pixel development for novel CMOS image sensors (Invited Paper) [7001-07]

G. Agranov, J. Ladd, T. Gilton, R. Mauritzson, U. Boettiger, X. Fan, X. Li, Aptina Imaging, Micron Technology, Inc. (USA)

700109 Inorganic color filters by MOCVD for CMOS imager and colorimetry [7001-08]

S. Guerroudj, STMicroelectronics (France) and Minatec (France); F. Roy, STMicroelectronics (France); J.-L. Deschanvres, Minatec (France)

7001 OA Characterizing spatial crosstalk effects in small pixel image sensors [7001-09]

R. L. Nicol, STMicroelectronics Ltd. (United Kingdom); C. P. Leahy, STMicroelectronics Ltd. (United Kingdom) and The Univ. of Edinburgh (United Kingdom); D. Renshaw, The Univ. of Edinburgh (United Kingdom) 
$7001 \mathrm{OB} \quad$ Embedded processor extensions for image processing [7001-10]

M. Thevenin, CEA, LIST (France); M. Paindavoine, LE2i, Univ. de Bourgogne (France);

L. Letellier, CEA, LIST (France); B. Heyrman, LE2i, Univ. de Bourgogne (France)

7001 OC Integration and characterization of spin on dielectric materials in image sensor devices [7001-11]

H. Reznik, R. S. Edelstein, M. Shach-Caplan, F. Dulberg, V. Kamenetsky, Tower

Semiconductor Ltd. (Israel); K. Karaste, J. T. Rantala, Silecs Oy (Finland)

\section{SESSION $3 \quad$ LASER AND LED PROJECTION}

7001 OD Visible lasers for mobile projection (Invited Paper) [7001-12]

U. Steegmüller, M. Kühnelt, H. Unold, T. Schwarz, R. Schulz, K. Auen, C. Walter, M. Schmitt, OSRAM Opto Semiconductors GmbH (Germany)

7001 OE Scanning laser beam displays (Invited Paper) [7001-13]

M. Niesten, R. Sprague, J. Miller, Microvision, Inc. (USA)

7001 OF Requirements on LEDs in etendue limited light engines [7001-15]

A. Wilm, OSRAM Opto Semiconductors GmbH (Germany)

\section{SESSION $4 \quad$ APPLICATIONS AND OPTICAL SUBSYSTEMS}

$7001 \mathrm{OH} \quad$ Optical design of a compact illumination system for LED projection displays [7001-17]

B. Van Giel, Y. Meuret, L. Bogaert, H. Thienpont, Vrije Univ. Brussel (Belgium)

$700101 \quad$ Optical links in handheld multimedia devices (Invited Paper) [7001-18]

S. van Geffen, J. Duis, Tyco Electronics (Netherlands); R. Miller, Tyco Electronics (USA)

7001 OJ Optical link utilizing polymer optical waveguides: application in multimedia device [7001-19]

Y. Ishida, H. Hosokawa, OMRON Corp. (Japan)

\section{POSTER SESSION}

$7001 \mathrm{OL} \quad$ Fractal dimension and neural network based image segmentation technique [7001-21] Q. Lin, G. Feng, Huaqiao Univ. (China)

$70010 M \quad$ A novel image fusion algorithm based on wavelet transforms [7001-22]

Q. Lin, G. Feng, Huaqiao Univ. (China)

$70010 N$ Design and fabrication of quartz-based micro prism array of dual-view display by using reactive ion etching [7001-23]

C.-Y. Chen, National Yunlin Univ. of Science and Technology (Taiwan); W.-C. Su, National Changhua Univ. of Education (Taiwan); T.-Y. Hsieh, National Yunlin Univ. of Science and Technology (Taiwan); J.-R. Sze, National Applied Research Labs. (Taiwan)

Author Index 


\title{
Conference Committee
}

\author{
Symposium Chairs \\ Hugo Thienpont, Vrije Universiteit Brussel (Belgium) \\ Patrick P. Meyrueis, Université Louis Pasteur (France) \\ Giancarlo C. Righini, Istituto di Fisica Applicata Nello Carrara, CNR \\ (Italy) \\ Conference Chairs
}

Ari Tervonen, Helsinki University of Technology (Finland)

Frank Möllmer, OSRAM Opto Semiconductors GmbH (Germany)

Program Committee

Janne K. Aikio, VTT Elektroniikka (Finland)

Jan T. Bosiers, DALSA Corporation (Netherlands)

Jacques W. Duparré, Fraunhofer-Institut für Angewandte Optik und Feinmechanik (Germany)

Martin Schrader, Nokia Research Center (Finland)

Michael Schwind, OSRAM Opto Semiconductors GmbH (Germany)

\author{
Session Chairs \\ $13 \mathrm{D}$ and Immersive Displays \\ Janne K. Aikio, VTT Elektroniikka (Finland) \\ 2 Camera Sensors and Signal Processing \\ Jan T. Bosiers, DALSA Corporation (Netherlands) \\ 3 Laser and LED Projection \\ Frank Möllmer, OSRAM Opto Semiconductors GmbH (Germany) \\ $4 \quad$ Applications and Optical Subsystems \\ Ari Tervonen, Helsinki University of Technology (Finland)
}


Downloaded From: https://www.spiedigitallibrary.org/conference-proceedings-of-spie on 26 Apr 2023

Terms of Use: https://www.spiedigitallibrary.org/terms-of-use 